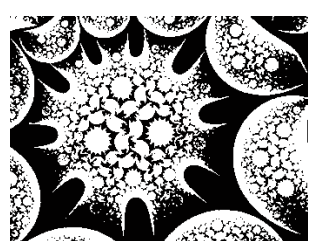

\title{
ASSESSMENT OF DRUG-RELATED PUBLIC EXPENDITURES IN CROATIA
}

Dubravka JURLINA ALIBEGOVIĆ, Sunčana SLIJEPČEVIĆ Institute of Economics, Zagreb

UDK: 351.761.3(497.5)"2009/2012"

Izvorni znanstveni rad

Primlieno: 15. 2. 2013.

Literature suggests that drug abuse is one of the major health and social problems in today's society. Croatia is no exception in this respect, although it belongs among the European countries with medium drug use prevalence. Consequently, the importance of evaluating public drug policy is growing. Public expenditures on combating drug problems are recognised as a very useful indicator of government efforts in this regard. This paper contains the results of the first research on drug-related public expenditures conducted in Croatia for the period between 2009 and 2012. Total drug-related public expenditures, including both labelled and unlabelled expenditures, are estimated and expenditures analysed according to the purpose for which these expenditures are intended. The estimation of drug-related public expenditures is based on data collected by means of a survey conducted among principal stakeholders in the field of combating drug abuse in Croatia. Also, the paper analyses expenditures according to the functional classification so as to gain an insight into more detailed purposes for which these expenditures are intended. The results show that the largest part of total public expenditures relates to the public function of public order and safety, while smaller drug-related expenditures are used for health, social protection and education.

Keywords: drug policy, public expenditures, evaluation, Croatia

Sunčana Slijepčević, Institute of Economics, Trg J. F. Kennedyja 7, 10000 Zagreb, Croatia. E-mail: suncana@eizg.hr 
Drug abuse is one of the leading health and social problems in today's society (WHO, 2010). Croatian drug policy was developed in the mid-1990s with the goal to decrease demand and supply of illicit drugs, as well as to mitigate the harmful effects of drug abuse (Office for Combating Drug Abuse of the Government of the Republic of Croatia, 2011). The main strategic document, The National Strategy on Combating Drug Abuse in the Republic of Croatia for the period 2006-2012, was implemented through three consecutive Action Plans aimed at "...a multidisciplinary integrated and effective approach to combating drug abuse at the national and local level" (Office for Combating Drug Abuse of the Government of the Republic of Croatia, 2011, p. 16). Besides the main goals, the 2009-2012 Action Plan defines twelve specific goals. Two of them clearly state that the goals are to encourage different programmes or scientific research in the drug-related field through the allocation of financial resources (Government of the Republic of Croatia, 2009). The drug-related research studies conducted in Croatia so far have mostly examined drug issues from a social perspective and the abuse of different types of drugs among the Croatian population (Itković, 1995; Sarić, Sakoman, \& Zdunić, 2002; Brajša-Žganec, Raboteg-Šarić, \& Glavak, 2002; Sakoman, Raboteg-Šarić, \& Kuzman, 2002). However, they have not answered the question about the amount of resources spent by the government on drug-related issues and the specific purposes for which the resources are used.

This paper bridges this gap in literature with two goals. The first is to propose a methodology for measuring drug-related expenditures. Every year, European Union member states allocate a part of their budget to dealing with the negative consequences of drug consumption and to prevention, but they still do not evaluate the efficiency of such spending. In the last decade, more than twenty European Union member states tried to estimate public expenditures, but because different countries apply different methodologies, data are largely incomparable (EMCDDA, 2012).

Estimation of total drug-related expenditures consists of two parts: (1) labelled drug-related expenditures and (2) unlabelled drug-related expenditures. Most of the European countries estimate only labelled drug-related expenditures and even in this regard the data are not comparable. They are still struggling with the budgetary reforms and reclassification of the budget on the basis of programmes or outputs. Many public bodies, departments and agencies that are involved in drug prevention or combating drug abuse still do not have an 
DRUŠ. ISTRAŽ. ZAGREB GOD. 24 (2015), BR. 1 STR. $1-20$

JURLINA ALIBEGOVIĆ, D., SLIJEPČEVIĆ, S.: ASSESSMENT OF.. adequate system of reporting and monitoring. Thus, different drug-related expenditures are visible in different countries' budgets. Due to different data quality and coverage, even the labelled expenditures for EU countries are only indicative and cannot be compared. Financial resources which are not visible directly in the budget are unlabelled and have to be estimated to get the full picture about resources used for drug-related purposes. This clearly indicates the need for a methodology that can be employed across all EU countries for evaluating public drug-related expenditures. By solving the problem of non-comparability, such a methodology would contribute to literature. Developing this methodology is the first goal of this paper. The second goal is to show how such a methodology could be used to measure drug-related public expenditures in the particular case of Croatia.

Kopp and Fenoglio (2003) stressed that measuring public expenditures is an important indicator for evaluating efforts invested by a government in dealing with drugs problems. Some central and local public bodies have data about drug-related public expenditures on the budgetary levels which are not publicly available (for example, data about used resources for specific prevention programmes which are visible in the budget as a project). Therefore, we have collected, using a questionnaire we developed, data from central and local public bodies and we estimated one part of the expenditures using a repartition key. In addition, we used the IMF (2001) functional classification of government expenses (COFOG) to estimate drug-related expenditure. The COFOG classification has the advantage of subdividing public expenditures on the basis of the purpose of public expenditure, thus providing valuable information on the final purpose of drug-related spending (public order and safety, health, education etc).

\section{LITERATURE REVIEW}

In the last few decades, due to very high and increasing public expenditures, governments in many countries have been under pressure to reduce spending and implement budgetary reforms aimed at a performance measurement and a budgetary output and outcome evaluation. In 1999, the European Union Action Plan to Combat Drugs (2000-2004) stressed that the evaluation of a drug policy needs to be an integral part of the European Union approach to fighting illicit drugs. The first step in the evaluation process is to measure drug-related expenditures. There is no unique methodology for measuring drug-related expenditures. Vander Laenen, Vandam, De Ruyver, and Lievens (2011) in a review of the research studies until 2010 about drug-related expenditures in Europe 
DRUŠ. ISTRAŽ. ZAGREB GOD. 24 (2015), BR. 1, STR. $1-20$

JURLINA ALIBEGOVIĆ D., SLIJEPČEVIĆ, $S$. ASSESSMENT OF... identified only ten papers dealing with this topic, with the first European study published in 2002. In that study Origer analysed drug-related expenditures in Luxembourg and concluded that over a half of the expenditures was used for demand and harm reduction. Kopp and Fenoglio (2003) tried to spread analysis to measure direct expenditures and indirect drug-related public expenditure in 16 European Union Member States.

The available literature highlights the existing problem of performing comparative analysis due to differing coverage and/or methodologies in different countries. Reuter, Ramstedt, and Rigter (2004) tried to measure public expenditures related to the implementation of drug policy in the Netherlands and Sweden, but concluded that the precision of current expenditures estimates is very low and that the comparison of results lacks credibility. In most of the literature, drug-related public expenditures are divided into four categories: prevention, treatment, harm reduction and law enforcement (see for example, Ramsted (2006) in Sweden; Rigter (2006) in the Netherlands; BICEPS (2010) in Latvia; Lievens, Vander Laenen, Caulkins, \& De Ruyver (2012) in Belgium, among others). However, it is only labelled expenditures that can be divided into these categories. Thus the EMCDDA suggests the use of a system based on detailed classification of the government's functions. This research paper contributes by proposing a methodology of using a set of repartition keys for the estimation of expenditures divided in categories according to its purpose (according to COFOG). The application of this proposed methodology in different countries, by enabling the estimation of unlabelled drug-related expenditures in European Union countries, contributes to getting more comparable results among these countries.

Very few research studies manage to divide total drug-related expenditures by the COFOG classification. National focal points or national drug observatories, which are national institutions or agencies responsible for data collection and reporting on drugs and drug addiction in each EU member state, in some countries tried to classify at least part of the total drug-related expenditures according to COFOG for the EMCDDA reports. Labelled drug-related expenditures can be classified within a COFOG by functions (1 ${ }^{\text {st }}$ level) and groups ( $2^{\text {nd }}$ level). However, the national focal points have not been able to estimate all unlabelled expenditures and also categorise them according to COFOG classification because of the lack of data or indicators for calculation of the attributable proportion for each function. However, there are some examples of estimations. One is from Origer (2009), who measured drug-related expenditures for health and public order and safety in Luxembourg in 2008. In 2006, an EMCDDA report 
DRUŠ. ISTRAŽ. ZAGREB GOD. 24 (2015), BR. 1 STR. $1-20$

JURLINA ALIBEGOVIĆ, D., SLIJEPČEVIĆ, S. ASSESSMENT OF..

(1) TABLE 1

Overview of approaches to analysing drug-related expenditures based on inputs from national focal points made a cross-country analysis of labelled expenditures and unlabelled expenditures for public order and safety and health expenditures for ten European countries. It found that labelled expenditures in European Union member states arise mainly from health (67 percent) and public order and safety expenditures (22 percent). On the contrary, estimated unlabelled expenditures in the analysed countries are related mostly to financing public order and safety (88 percent), and to a minor extent to health (12 percent).

Researchers use different approaches to estimating drug-related expenditures as could be seen from the literature overview given in Table 1 . These are the top-down, bottom-up and mixed approaches. Also, theoretical and empirical studies systematise costs associated with drug addiction as public, private or external expenditures. In addition, the literature overview given in Table 1 shows the attempts by some authors to estimate at least one part of the total drug-related public expenditures in European Union countries.

\begin{tabular}{ll}
\hline $\begin{array}{l}\text { Approach/ } \\
\text { methodology used }\end{array}$ & Reference \\
\hline $\begin{array}{l}\text { Estimation of drug- } \\
\text {-related public } \\
\text { expenditures by }\end{array}$ & Prieto (2010) \\
$\begin{array}{l}\text { COFOG classification } \\
\text { Estimation of drug- }\end{array}$ & Babor et al. (2010) \\
-related public \\
$\begin{array}{l}\text { expenditures by } \\
\text { Reuter's classification }\end{array}$ \\
\\
$\begin{array}{l}\text { Drug-related public } \\
\text { expenditures/costs } \\
\text { (public, private, external) }\end{array}$ & \\
\hline
\end{tabular}

Top-down, bottom-up and mixed approach
Moeller (2012)
Short description

Labelled drug-related expenditures in $10 \mathrm{EU}$ member states are analysed and classified according to the COFOG and in relation to the gross domestic product.

Drug policy expenditures are divided by Reuter classification in four categories of expenditures according to the activities they belong to. These are: prevention, treatment, harm reduction and law enforcement.

Provides an explanation for the definition of cost and analyses the studies systematising costs associated with drug addiction in different ways. The costs associated with drug addiction are divided into two major groups, as "cost to society" and "external cost". The definition of cost necessarily means a comparison between all practically expected consequences (positive and negative) of the two alternatives (free will and addiction).

Direct costs of policing are estimated and disaggregated into two categories: relating to retail-level and crackdowns. Costs for retail-level policing are estimated using a micro-costing and a gross-costing approach. Crackdowns are estimated on the basis of available data. 
(4) TABLE 1 (continued)

Approach/

methodology used

Reference

Short description

Top-down, bottom-up

Raftery (2000)

Debates different strategies that can be used to and mixed approach

bottom-up, gross-costing or top-down and a mixture of the two, using micro-costing for the direct costs of the intervention and gross-costing for other costs.

Postma (2004) Describes the top-down approach to estimate public drug-related expenditures. In this methodology the first step is to identify public authorities involved in the drug policy. The second step is the collection and analysis of data in the public authorities' drug budgets.

Kopp and

The bottom-up approach is used to estimate

Fenoglio (2003) public spending on drugs in the European Union.

De Ruyver, Cassel-

Combines top-down and bottom-up approachman, and Pelc (2004)

es. This method provides an opportunity for verification of collected data on drug policy.

Measuring the outcomes Ritter (2009) Describes three drug policy indexes for measurof different policies ing the outcomes of different illicit drug policies. These are: the United Nations Office on Drugs and Crime (UNODC) Illicit Drug Index, the UK Drug Harm Index and the Australian Federal Police Drug Harm Index. The purpose of the indexes is to explain the outcomes of effective drug policy, monitor performance over time within a country/region; establishing social costs saved; comparisons between countries or regions; and policy analysis.

\section{KEY CHARACTERISTICS AND METHODOLOGY}

The analysis of public expenditures in Croatia has so far been based on the reports of ministries sent to the Office for Combating Drug Abuse of the Government of the Republic of Croatia. However, a comprehensive analysis of total expenditures for implementation of the 2009-2012 National Strategy and Action Plan was not conducted because authorities responsible for the implementation of particular measures do not have separately specified activities, projects or programmes related to drug issues within their budgets. Thus, they do not show explicitly what resources are allocated to drug-related activities. 
DRUŠ. ISTRAŽ. ZAGREB GOD. 24 (2015), BR. 1 STR. $1-20$

JURLINA ALIBEGOVIĆ, D., SLIJEPČEVIĆ, $S$. ASSESSMENT OF...
To ensure international comparability of drug-related public spending in Croatia with other European countries, EMCDDA methodological guidelines were followed. The EMCDDA distinguish two categories of the total drug-related expenditures: labelled and unlabelled expenditures. The EMCDDA (2008, p. 11) defines labelled expenditure as "the planned ex-ante expenditure that reflects the voluntary commitment of the state in the field of drugs". Such expenditures can be identified by analysing detailed budget and/or fiscal year-end accounting reports. There are other definitions of labelled drug-related public expenditure as well. According to one of them, labelled expenditure is the direct expenditure explicitly labelled as related to illicit drugs by the general government (Prieto, 2010). In the questionnaire administered by us, public authorities were asked to identify current and capital drug-related expenditures spent in the 2009-2011 period or planned to be spent in 2012 .

In this research we follow the above definition of labelled public expenditures. Labelled expenditure signifies the public expense that in its name contains any of the following keywords: "prevention programme", "drug abuse and addiction," "social reintegration", "addiction treatment". It can also include similar activities recorded as special programmes, activities or projects, whether these are in the state budget, in the budgets of regional and local governments or in the financial plans and budgets of public bodies and other institutions whose activities are aimed at different aspects of combating drug abuse and at drug prevention.

The EMCDDA (2008) defines unlabelled expenditure as the non-announced or non-planned public expenditure faced by the general government in tackling drug issues. As already mentioned in the previous section, the literature recognises the top-down and the bottom-up approach to measuring expenditures. Although many European Union member states still do not estimate unlabelled drug-related expenditures, those which do, use varying approaches. According to EMCDDA (2004), France, UK and Spain use the bottom-up approach, Sweden and the Netherlands the top-down approach while Belgium uses both.

This paper uses a combination of the top-down and the bottom-up approach. The top-down approach is used when the data on total expenditures devoted to fighting addiction are known, but it is necessary to estimate only drug-related expenditures. On the other hand, the bottom-up approach is used to estimate the drug-related expenditures for those activities for which the overall budget is not known. In such cases we had to estimate it by using other statistical data, such 
DRUŠ. ISTRAŽ. ZAGREB GOD. 24 (2015), BR. 1, STR. 1-20

JURLINA ALIBEGOVIĆ D., SLIJEPČEVIĆ, S ASSESSMENT OF...

(1) TABLE 2

Public institutions' activities for drug-related issues according to public functions as the work time spent by school teachers on drug-related activities.

The institutions involved in combating drug abuse in Croatia and their activities according to functional classification of public functions are presented in Table 2. In addition to the Office for Combating Drug Abuse of the Government of the Republic of Croatia, several ministries and public institutions at the central level, counties and institutions at the county level, the city of Zagreb, and civil society organisations whose predominant activities focused on prevention programmes, treatment and re-socialisation of addicts, were included in the analysis.

\begin{tabular}{|c|c|c|c|c|c|c|}
\hline \multirow[b]{2}{*}{ Type of institution } & \multirow[b]{2}{*}{ Institution } & \multicolumn{5}{|c|}{ Public function } \\
\hline & & 01 & 03 & 07 & 09 & 10 \\
\hline Ministries & $\begin{array}{l}\text { The Office for Combating Drug Abuse } \\
\text { of the Government of the Republic of Croatia } \\
\text { Ministry of Health } \\
\text { Ministry of Social Policy and Youth } \\
\text { Ministry of Defence } \\
\text { Ministry of Science, Education and Sports } \\
\text { Ministry of the Interior } \\
\text { Ministry of Finance - Customs Administration } \\
\text { Ministry of Justice }\end{array}$ & & $\begin{array}{l}x \\
x \\
x\end{array}$ & $\begin{array}{l}x \\
x\end{array}$ & $\begin{array}{l}x \\
x\end{array}$ & $x$ \\
\hline $\begin{array}{l}\text { Public institutions } \\
\text { at state level }\end{array}$ & $\begin{array}{l}\text { Croatian Institute for Health Insurance } \\
\text { Croatian National Institute of Public Health } \\
\text { Croatian Employment Service }\end{array}$ & & & $\begin{array}{l}x \\
x\end{array}$ & $\mathrm{x}$ & $x$ \\
\hline Counties & 21 counties & $x$ & $x$ & $x$ & $x$ & $x$ \\
\hline $\begin{array}{l}\text { Public institutions } \\
\text { at county level }\end{array}$ & County Institutes of Public Health & & & $\mathrm{x}$ & & \\
\hline $\begin{array}{l}\text { Civil society } \\
\text { organisations }\end{array}$ & 8 civil society organisations & & $\mathrm{x}$ & $\mathrm{x}$ & $\mathrm{x}$ & $\mathrm{x}$ \\
\hline te & & & $\begin{array}{l}\text { neral } \\
\text { blic o } \\
\text { ealth } \\
\text { ucati } \\
\text { cial p }\end{array}$ & otec & & \\
\hline
\end{tabular}

All programmes, activities and projects undertaken by public institutions can be grouped into five basic public functions: general public services, public order and safety, health, education and social protection. Counties are involved in the activities within the sphere of all public functions, but mostly within public health and education. Civil society organisations carry out tasks that are mostly included in health, education and social protection. 
DRUŠ. ISTRAŽ. ZAGREB GOD. 24 (2015), BR. 1 STR. $1-20$

JURLINA ALIBEGOVIĆ, D., SLIJEPČEVIĆ, $S$. ASSESSMENT OF..
The data from key stakeholders (Table 2) in the field of combating drug abuse were collected through a structured questionnaire. Stakeholders were asked about the level of expenditures used for drug-related activities, projects or programmes and the final purpose for which the expenditures were used. It has to be stressed that the Ministry of Health and the Croatian Institute for Health Insurance finance civil society organisations. As the aim of this paper is to see the final purpose of resources, the expenditures of the Ministry of Health and the Croatian Institute for Health Insurance are decreased for the drug-related expenditures of civil society organisations.

\section{DRUG-RELATED EXPENDITURES BY PUBLIC FUNCTIONS}

\section{Labelled public expenditures}

According to stakeholders, the labelled drug-related expenditures have been on an increase since 2009. They rose from HRK 93.5 million in 2009 to 102.8 million in 2011 (Table 3). The share of labelled expenditures of ministries in total public drug-related expenditures decreased from 38.1 percent in 2009 to 31.6 percent in 2011. At the same time, the share of labelled drug-related public expenditures of public institutions at the state level in the total drug-related public expenditures increased from 45.2 percent in 2009 to 57.3 percent in 2011. The share of labelled drug-related expenditures in county budgets decreased from 13.7 percent (2009) to 7.6 percent (2011). The proportion of civil society organisations in labelled drug-related expenditures increased from 2.9 percent to 3.5 percent during the period between 2009 and 2011. A significantly lower amount was planned for 2012 .

\section{$\rightarrow$ TABLE 3 \\ Labelled drug-related public expenditures in HRK 000}

\begin{tabular}{lrrrr}
\hline & & & & Plan \\
& 2009 & 2010 & 2011 & 2012 \\
\hline Ministries & 35,643 & 34,099 & 32,458 & 26,040 \\
Public institutions at state level & 42,261 & 53,004 & 58,953 & 48,871 \\
Counties & 12,833 & 10,230 & 7,792 & 9,493 \\
Civil society organisations & 2,728 & 2,646 & 3,624 & 3,173 \\
Total & 93,465 & 99,979 & 102,827 & 87,577 \\
\hline
\end{tabular}

Source: Questionnaire; Annual reports on the execution of the county budgets, 2009-2011; Plan of the county budgets for 2012; Government of the Republic of Croatia (2012).

Public authorities could not divide all labelled expenditures according to the public function classification. Some 87 percent of the total amount of labelled expenditures has been 
DRUŠ. ISTRAŽ. ZAGREB GOD. 24 (2015), BR. 1, STR. $1-20$

JURLINA ALIBEGOVIĆ D., SLIJEPČEVIĆ, $S$ ASSESSMENT OF... divided and analysed according to the COFOG classification in order to analyse the final purpose of that spending (Table 4). The residual could not be analysed by public function since neither an exhaustive analysis of state budget and documents nor the information we obtained from interviews with representatives of stakeholders gave us enough information.

\begin{tabular}{lrrrr}
\hline Public function & 2009 & 2010 & 2011 & Plan 2012 \\
\hline 03 Public order and safety & 0 & 7,848 & 3,378 & 0 \\
031 Police and customs services & 0 & 7,848 & 3,378 & 0 \\
Health & 60,782 & 65,944 & 71,237 & 60,839 \\
071 Medical products, supplies and equipment & 26,743 & 37,580 & 39,622 & 28,887 \\
072 Outpatient services & 110 & 110 & 0 & 0 \\
073 Hospitals & 600 & 840 & 1,040 & 520 \\
074 Public health services & 33,271 & 27,356 & 30,517 & 31,374 \\
075 R\&D & 58 & 58 & 58 & 58 \\
Education & 834 & 597 & 586 & 1,779 \\
091 Primary education & 364 & 219 & 208 & 500 \\
092 Secondary education & 364 & 219 & 208 & 500 \\
095 Education that cannot be classified by degree & 84 & 137 & 147 & 685 \\
096 Additional services in education & 22 & 22 & 23 & 94 \\
Social protection & 6,114 & 5,390 & 4,992 & 5,048 \\
105 Unemployment & 160 & 220 & 277 & 333 \\
107 Social assistance to households that are not & & & & \\
covered by regular social programmes & 5,954 & 5,170 & 4,715 & 4,715 \\
Ministries and public institutions at central level & 67,730 & 79,777 & 80,191 & 67,666 \\
Counties & 9,005 & 8,078 & 7,082 & 8,388 \\
Civil society organisations & 1,299 & 1,271 & 2,132 & 1,611 \\
Total & 78,034 & 89,126 & 89,405 & 77,665 \\
\hline
\end{tabular}

(1) TABLE 4

Estimation of labelled public expenditures by the COFOG classification, in HRK 000
Source: Questionnaire; Annual reports on the execution of the county budgets, 2009-2011 and Plan of the county budgets for 2012.

The allocation of labelled drug-related public expenditure has changed over the analysed period. All institutions reported labelled expenditures for health, education and social protection COFOG functions. Most of the labelled drug-related public expenditure has been used primarily for health (80 percent in 2011), specifically for the public health service and medical products, supplies and equipment. Ministries, counties and civil society organisations reported labelled expenditures for police services and the prison system.

\section{Unlabelled public expenditures}


DRUŠ. ISTRAŽ. ZAGREB GOD. 24 (2015), BR. 1 STR. $1-20$

JURLINA ALIBEGOVIĆ, D., SLIJEPČEVIĆ, $S$. ASSESSMENT OF.. ties. Therefore, drug-related expenditures are not visible in their budgets. We follow the methodology developed by Kopp and Fenoglio (2003), Postma (2004), EMCDDA (2008), Origer (2009), Prieto (2010) and Moeller (2012) according to which unlabelled public expenditure can be approximated by applying a certain "repartition key" on different drug-related activities. This methodology assumes that the unlabelled public spending to prevent drug abuse is a portion of the public expenditure that remains after reducing the total public expenditure of any public body for the amount of labelled drug-related public expenditure. Unlabelled drug-related public expenditures of each public authority are calculated using the following formula:

$\begin{array}{lc}\begin{array}{l}\text { Unlabelled } \\ \text { drug-related } \\ \text { public } \\ \text { expenditures }\end{array} & \text { (total public expenditures } \\ -\end{array}$

We propose "repartition keys" using different international databases. Though we illustrate our methodology in the specific case of Croatia, the method is general and can be applied to other countries using these databases. The Table in the Annex contains a detailed list of all international databases and sources. Where it is possible, we propose the usage of two or more indicators to get more precise results. In such cases, we calculate the repartition key as the average value of indicators. In cases where it has not been possible to use international databases, we have used publicly available data from national statistical sources, as well as from relevant public bodies. Table 5 contains a description of "repartition keys" for each public function.

We give two examples of how the repartition keys that we have proposed can be used. The first application is in the case of unlabelled expenditure within health care services. The data are calculated as a share of two items of publicly available data: the total number of hospital beds and the number of hospital beds used for the treatment of drug-induced disorders. Knowing the total number of hospital beds as well as the number of hospital beds used for the treatment of drug-induced disorders, we may calculate the ratios as indicated in Table 5. The calculated value of this indicator is 0.46 percent. To estimate unlabelled expenditures in the health sector, the total expenditures of the Croatian Institute for Health Insurance aimed at primary and hospital care are therefore multiplied by 0.46 . The obtained result for health is presented in Table 6. 


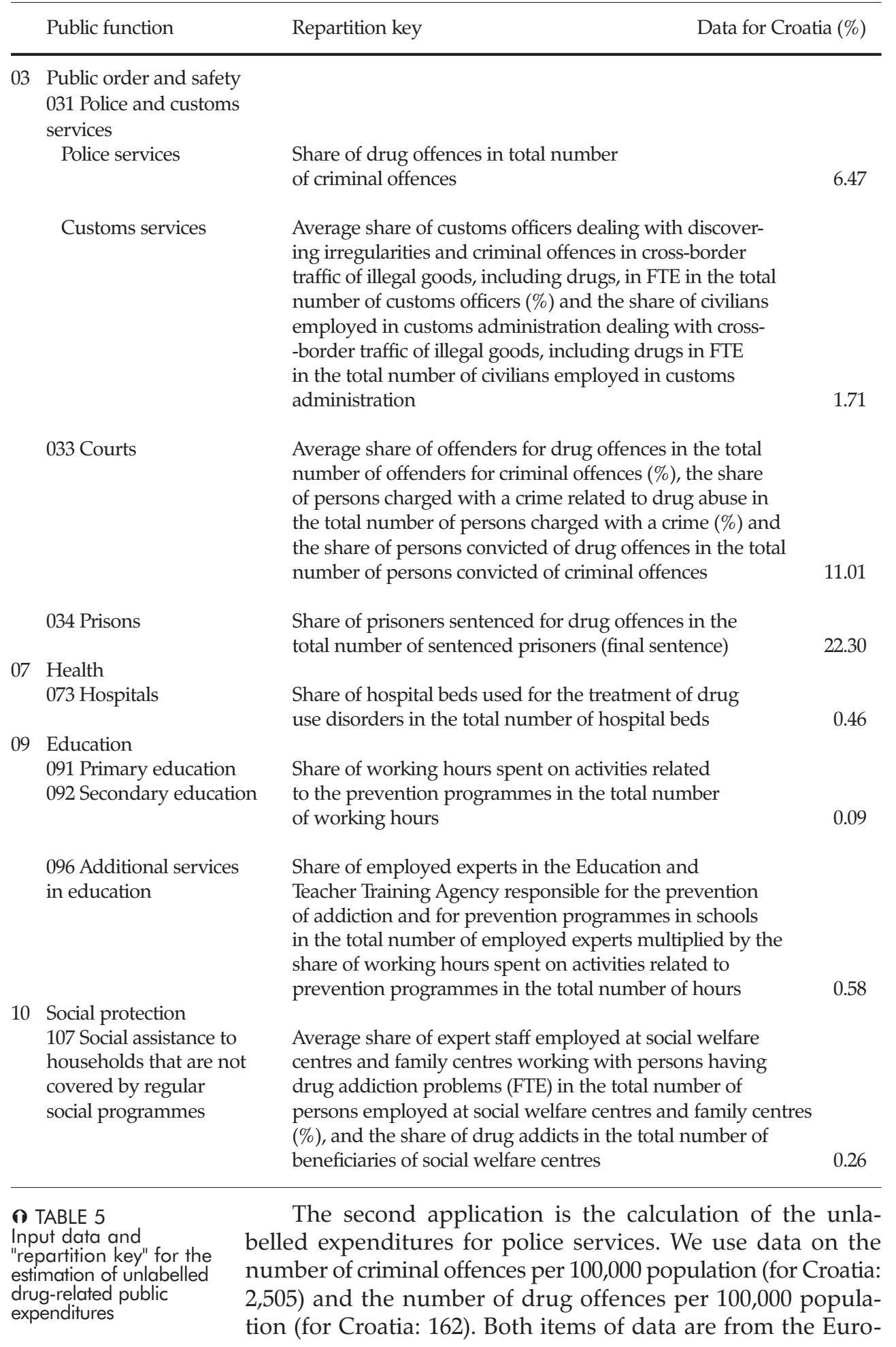


(1) TABLE 6

Estimation of unlabelled drug-related public expenditures by COFOG classification, in HRK 000 pean Sourcebook of Crime and Criminal Justice Statistics where the data for other countries are available as well. From those two numbers we calculated the share of drug offences in the total number of criminal offences (for Croatia: 6.47\%). By multiplying this result with total expenditure from the state budget (for Croatia: HRK 4,146 million), we obtain the result that for drug-related activities the police spent HRK 268.3 million. The estimation of unlabelled public expenditures for other public functions was made in a similar manner.

\begin{tabular}{|c|c|c|c|c|c|}
\hline \multicolumn{2}{|c|}{ Public function } & 2009 & 2010 & 2011 & Plan 2012 \\
\hline \multirow{4}{*}{03} & Public order and safety & 578,034 & 571,522 & 593,431 & 566,342 \\
\hline & 031 Police and customs services & 290,860 & 288,119 & 299,102 & 293,311 \\
\hline & 033 Courts & 175,179 & 171,024 & 174,172 & 162,516 \\
\hline & 034 Prisons & 111,994 & 112,378 & 120,156 & 110,513 \\
\hline \multirow[t]{2}{*}{07} & Health & 52,151 & 51,780 & 51,234 & 49,833 \\
\hline & 073 Hospitals & 52,151 & 51,780 & 51,234 & 49,833 \\
\hline \multirow[t]{4}{*}{09} & Education & 5,070 & 4,715 & 4,799 & 4,507 \\
\hline & 091 Primary education & 2,877 & 2,898 & 2,953 & 2,757 \\
\hline & 092 Secondary education & 1,540 & 1,568 & 1,608 & 1,523 \\
\hline & 096 Additional services in education & 652 & 248 & 236 & 226 \\
\hline \multirow[t]{2}{*}{10} & Social protection & 695 & 688 & 668 & 669 \\
\hline & $\begin{array}{l}107 \text { Social assistance to households that are } \\
\text { not covered by regular social programmes }\end{array}$ & 695 & 688 & 668 & 669 \\
\hline \multicolumn{2}{|r|}{$\begin{array}{l}\text { Ministries and public institutions } \\
\text { at central level }\end{array}$} & 635,950 & 628,706 & 650,134 & 621,352 \\
\hline
\end{tabular}

Total unlabelled public expenditures reached between HRK 628 million in 2010 and 650 million in 2011 (Table 6). They are between 7.9 and 9.4 times higher than labelled public expenditures (Table 3). Unlabelled public expenditures can be divided into four public functions: public order and safety, health, education and social protection. The vast majority of unlabelled public expenditures is used to achieve public order and safety (91.3 percent). Less than 10 percent of the total unlabelled drug-related public expenditures is used for health, education and social protection.

\section{Total drug-related public expenditures}

Total drug-related expenditures are measured on the basis of the labelled and estimated unlabelled expenditures. In 2011, they reached HRK 741.8 million (Table 7). Most of these expenditures are used for public order and safety (81.7 percent in 2011), and the remainder is used for financing health, education and social protection. 


\begin{tabular}{|c|c|c|c|c|c|}
\hline \multicolumn{2}{|c|}{ Public function } & \multirow{2}{*}{$\begin{array}{r}2009 \\
0\end{array}$} & \multirow{2}{*}{$\frac{2010}{8}$} & \multicolumn{2}{|c|}{2011 Plan 2012} \\
\hline \multirow{2}{*}{02} & Defence & & & 4 & 28 \\
\hline & 025 Defence, not elsewhere classified & 0 & 8 & 4 & 28 \\
\hline \multirow[t]{4}{*}{03} & Public order and safety & 578,034 & 579,369 & 596,809 & 566,342 \\
\hline & 031 Police and customs services & 290,860 & 295,966 & 302,480 & 293,311 \\
\hline & 033 Courts & 175,179 & 171,024 & 174,172 & 162,516 \\
\hline & 034 Prisons & 111,994 & 112,378 & 120,156 & 110,513 \\
\hline \multirow[t]{6}{*}{07} & Health & 112,933 & 117,723 & 122,471 & 110,672 \\
\hline & 071 Medical products, supplies and equipment & 26,742 & 37,580 & 39,621 & 28,886 \\
\hline & 072 Outpatient services & 110 & 110 & 0 & 0 \\
\hline & 073 Hospitals & 52,751 & 52,620 & 52,274 & 50,353 \\
\hline & 074 Public health services & 33,271 & 27,355 & 30,517 & 31,374 \\
\hline & $075 \mathrm{R} \& \mathrm{D}$ & 57 & 57 & 57 & 57 \\
\hline \multirow[t]{5}{*}{09} & Education & 5,904 & 5,311 & 5,384 & 6,286 \\
\hline & 091 Primary education & 3,241 & 3,117 & 3,162 & 3,257 \\
\hline & 092 Secondary education & 1,904 & 1,787 & 1,816 & 2,023 \\
\hline & 095 Education that cannot be classified by degree & 83 & 136 & 146 & 684 \\
\hline & 096 Additional services in education & 674 & 270 & 259 & 320 \\
\hline \multirow[t]{4}{*}{10} & Social protection & 6,808 & 6,078 & 5,660 & 5,717 \\
\hline & 105 Unemployment & 159 & 219 & 276 & 333 \\
\hline & 107 Social assistance to households that are & & & & \\
\hline & not covered by regular social programmes & 6,648 & 5,858 & 5,383 & 5,384 \\
\hline \multicolumn{2}{|r|}{ Ministries and public institutions at central level } & 703,680 & 708,491 & 730,330 & 689,046 \\
\hline \multicolumn{2}{|r|}{ Counties } & 12,832 & 10,229 & 7,792 & 9,492 \\
\hline \multicolumn{2}{|r|}{ Civil society organisations } & 2,727 & 2,645 & 3,624 & 3,173 \\
\hline \multicolumn{2}{|c|}{ Total } & 719,241 & 721,367 & 741,747 & 701,712 \\
\hline
\end{tabular}

(i) TABLE 7

Estimation of total drug-related public expenditures by COFOG classification in HRK 000
Conducted analysis and estimation of drug-related expenditures should be seen as only one small step in the process of evaluating the government drug-related policy. To better illustrate the resources spent on different drug-related programmes and activities, expenditures per addicted person could be observed (Table 8). The drug-related expenditures per addicted person have been on an increase. These results further imply the necessity to evaluate the efficiency of government spending by analysing the successfulness of different government programmes and activities, such as education and other activities aimed at prevention.

It appears that public spending on combating drug abuse, according to our estimation, is responsible for a relatively large share of public expenditure. The Croatian government spends around 0.5 percent of the total public expenditures or 0.2 percent of GDP on drug policy. Since the methodology for drug-related expenditures is still being developed, it is impossible to make any international comparison. Having in mind 
DRUŠ. ISTRAŽ. ZAGREB GOD. 24 (2015), BR. 1 STR. $1-20$

JURLINA ALIBEGOVIĆ, D., SLIJEPČEVIĆ, S. ASSESSMENT OF..

(1) TABLE 8

Total drug-related expenditures per addicted person the seriousness of the problem of drug addiction and drug abuse, it can be assumed that spending this amount of public money is reasonable, but only if it can be demonstrated that it has been spent effectively. As Meara and Frank (2005) noticed, the question of determining the optimal level of spending, meaning the spending that minimises social costs, is an important research topic. To answer this question, each public policy should make a clear distinction between the potential impact of spending and its actual impact. This means that it would be necessary to analyse whether the drug-related spending results in the desired social and economic outcomes. Besides the measurement of drug-related expenditures, it is necessary to establish a set of performance indicators which would then be analysed, together with expenditures in each public function. Performance indicators should give an answer to the question whether the desired outputs and outcomes have been achieved. The establishment of the performance measurement system in this field requires identification of the goal (desired) value and monitoring of the achieved value of each indicator. In Croatia, the two main goals identified in the main strategic documents in the field of combating drug abuse are: to decrease the drugs demand and to decrease the supply of drugs. For each of these goals, the set of performance indicators should be identified. Examples of these indicators are: number of addicted persons per citizen, number of addicted persons - minors per citizen, number of deaths caused by drug use or in the connection with the use of drugs etc. The identification of performance indicators depends on the available data, but such a system should enable the identification of programmes, projects or activities which are successful and worthy of replication. For those which are not successful in achieving the desired results, the reasons of failure should be carefully analysed.

\begin{tabular}{lrrr}
\hline & 2009 & 2010 & 2011 \\
\hline Total drug-related expenditures, in HRK & $719,241,110$ & $721,367,271$ & $741,747,521$ \\
Number of addicted persons & 7,733 & 7,550 & 7,665 \\
Drug-related expenditures per addicted person, in HRK & 93,009 & 95,545 & 96,771 \\
\hline
\end{tabular}

\section{CONCLUSIONS}

Drug abuse in modern society is a global phenomenon. The government in every country is the key actor in creating a drug prevention policy and fighting drug abuse. Croatia is no exception. The assessment of drug-related public expenditures is an important step in the evaluation of government efforts in dealing with drug problems. This paper contains the results of the first comprehensive study on drug-related public expen- 
DRUŠ. ISTRAŽ. ZAGREB GOD. 24 (2015), BR. 1, STR. $1-20$

JURLINA ALIBEGOVIĆ D., SLIJEPČEVIĆ, $S$. ASSESSMENT OF... ditures in Croatia. It covers labelled public expenditures and establishes a methodology for the assessment of unlabelled public expenditure in the field of combating drug abuse and drug addiction. Due to the fact that European countries apply different methodologies to estimate drug-related public expenditures, the application of the proposed methodology and repartition keys for estimating unlabelled expenditures should enable the comparison of results during time and between countries.

The results show that total drug-related expenditures reached HRK 741.8 million or 0.2 percent of GDP in 2011. The division of total expenditures according to the COFOG classification of public functions shows that the vast majority of total drug-related public expenditures are used to improve public order and safety. Health is evidently the dominant labelled expenditure, while public order and safety is the main unlabelled expenditure. Quite different structures of labelled and unlabelled public expenditures in the field of combating drug abuse and drug addiction imply that all stakeholders need to improve their budgets. Such improved transparency would, in turn, enable them to better track what purpose they use their resources for. In an ideal scenario, all drug-related expenditures should be labelled and clearly visible in the budget as a separate comprehensive programme. Then, the performance measurement would be possible and efficiency of the resources used for drug-related issues could be analysed. Performance and efficiency measurement would enable better monitoring of activities, projects and programmes over time and reallocation of resources to achieve the optimal level of drug-related spending in each public function, while improving results.

Although this research reveals the level of total drug-related expenditure and its allocation, it represents only one part of the analysis that should be conducted. It would be desirable to do additional research on the total costs of drug use for the society (social costs). Besides public drug-related expenditures, in order to estimate the social costs of drug abuse in the society, it would be necessary to measure private and external drug-related expenditures as well. Thus, the results presented in this paper can be seen as an analytical background for an assessment of the social cost of drug abuse in Croatia.

\section{ACKNOWLEDGEMENT}

This research is conducted as a part of the research project "Public expenditures and the establishment of performance indicators in the field of combating drug abuse in the Republic of Croatia" agreed between the Institute of Economics, Zagreb and Office for Combating Drug Abuse of the Government of the Republic of Croatia, which has provided support for the project. 
ANNEX

Year to

which

Public function / Data / Indicator

data refers Source

Number of criminal offences per 100,000 inhabitants

2007 European Sourcebook

Number of drug offences per 100,000 inhabitants

of Crime and Criminal

Number of persons convicted of criminal offences per 100,000 inhabitants Justice Statistics - 2010

Number of persons convicted of drug offences per 100,000 inhabitants

Number of offenders in criminal offences per 100,000 inhabitants

Number of offenders in drug offences per 100,000 inhabitants

Number of customs officers

Number of customs officers dealing with discovering irregularities and criminal offences in cross-border traffic of illegal goods, including drugs

Number of civilians employed in customs administration

Number of civilians employed in customs administration dealing with cross-border traffic of illegal goods, including drugs in FTE

Number of persons charged with a crime

Number of persons charged with a crime related to drug abuse

2011 Annual Report of the State Attorney for 2011

Number of sentenced prisoners (final sentence)

Number of prisoners sentenced for drug offences (final sentence)

2010 SPACE I Annual Penal Statistics of the Council of Europe

Hospital beds per 10,000 inhabitants

Beds for the treatment of alcohol and drug use disorders per 100,000 inhabitants

Beds for the treatment of alcohol use disorders per 100,000 inhabitants

Beds for the treatment of drug use disorders per 100,000 inhabitants

Total number of employed experts in the Education and Teacher Training Agency

Number of experts in the Education and Teacher Training Agency responsible for working with school pedagogists and psychologists dealing with prevention of addiction and with prevention programmes in schools

Number of experts' working days spent on addiction prevention programmes

Total number of working days (excluding holidays)

Number of customs officers dealing with discovering irregularities and criminal offences in cross-border traffic of illegal goods, including drugs in FTE

Number of working hours

Number of persons employed at the social welfare centres and family centres

Number of expert staff employed at the social welfare centres and family centres working with persons having drug addiction problems (FTE)

Number of beneficiaries of social welfare centres

Number of drug addicts who are beneficiaries of social welfare centres

2008 World Health Organisation, Global Health Observatory Data Repository

Education and Teacher Training Agency, unofficial data

2011 Experts' estimation 
Babor, T. F., Caulkins, J. P., Edwards, G., Fischer, B., Foxcroft, D. R., Humphreys, K., Obot, I. S., Rehm, J., Reuter, P., Room, R., Rossow, I., \& Strang, J. (2010). Drug policy and the public good. Oxford: Oxford University Press.

BICEPS (2010). Budget and non-budget social costs of drug abuse in Latvia in 2008. Analytical report by BICEPS for Centre of Health Economics. Baltic international centre for economic policy studies, March. Available at http://vec.gov.lv/uploads/files/4d39483928d40.pdf

Brajša-Žganec, A., Raboteg-Šarić, Z., \& Glavak, R. (2002). Gender differences in the relationship between some family characteristics and adolescent substance abuse. Društvena istraživanja, 11(2-3), 335-352.

Communication from the Commission to the Council and the European Parliament on a European Union Action Plan to Combat Drugs (20002004). Available at http://eeas.europa.eu/drugs/docs/ap00_04_en.pdf

De Ruyver, B., Casselman, J., \& Pelc, I. (2004). Drug policy in figures. Study of the actors involved, cost price calculation and population reached. Ghent: Academia Press.

EMCDDA (2004). Public expenditure on drugs in the European Union 2000-2004. EMCDDA Scientific report. Lisbon: EMCDDA. Available at http://snapshot.emcdda.europa.eu/attachements.cfm/att_5626_ EN_final\%20expenditure.pdf

EMCDDA (2008). Towards a better understanding of drug-related public expenditure in Europe. Selected issue. Luxembourg: Office for Official Publications of the European Communities. Available at http://www. drugs.ie/resourcesfiles/ResearchDocs/Europe/Research/2008/TDSI08 001ENC_WEB.pdf

EMCDDA (2012). EMCDDA trend report for the evaluation of the 2005-12 EU drugs strategy. Lisbon: EMCDDA. Available at http://www. emcdda.europa.eu/attachements.cfm/att_154968_EN_Trend\% 20report.pdf

Government of the Republic of Croatia (2009). Action plan on combating drug abuse in the Republic of Croatia for the period 2009-2012. Available at http://www.mfin.hr/adminmax/docs/STRATEGIJA_ VLADINIH_PROGRAMA_za_razdoblje_2010.-2012..pdf

Government of the Republic of Croatia (2012). Report on implementation of the National strategy and Action plan on combating drug abuse in the Republic of Croatia for 2011. Zagreb: The Government of the Republic of Croatia.

IMF (2001). Government Finance Statistics Manual 2001. Washington, D.C., International Monetary Fund.

Itković, Z. (1995). Roditelji kao odgojitelji. Uloga obiteljskog odgoja $\mathrm{u}$ prevenciji zloupotrebe droga (Parents as educators. The role of family in drug abuse prevention). Društvena istraživanja, 4(4-5), 575-586.

Kopp, P., \& Fenoglio, P. (2003). Public spending on drugs in the European Union during the 1990s. In EMCDDA (2003), Public spending on drugs in the European Union during the 1990s. EMCDDA Scientific report. Lisbon: EMCDDA. 
DRUŠ. ISTRAŽ. ZAGREB GOD. 24 (2015), BR. 1 STR. $1-20$

JURLINA ALIBEGOVIĆ, D., SLIJEPČEVIĆ, $S$. ASSESSMENT OF.
Lievens, D., Vander Laenen, F., Caulkins, J., \& De Ruyver, B. (2012). Drugs in figures III, Study of public expenditures on drug control and drug problems. In M. Cools, B. De Ruyver, \& M. Easton (Eds.), European criminal justice and policy (GofS) - Governance of Security Research Paper Series. Antwerp, Belgium: Maklu.

Meara, E., \& Frank, R. G. (2005). Spending on substance abuse treatment: How much is enough? Addiction, 100(9), 1240-1248. doi:10. 1111/j.1360-0443.2005.01227.x

Melberg, H. O. (2010). Conceptual problems with studies of the social cost of alcohol and drug use. Nordic Studies on Alcohol and Drugs, 27(4), 287-303.

Moeller, K. (2012). Estimating drug policy expenditures: Direct costs of policing cannabis in Copenhagen 2000-2009. Drugs: Education, Prevention, and Policy, 19(5), 379-386. doi:10.3109/09687637.2012.658888

National strategy on combating drug abuse in the Republic of Croatia. Official Gazette, 147/2005.

Office for Combating Drug Abuse of the Government of the Republic of Croatia (2011). Croatian report on the drug situation 2011, Zagreb, Croatia.

Origer, A. (2009). 2009 National Report (2008 data) to the EMCDDA by the Reitox National Focal Point "Grand Duchy of Luxembourg": New development, trends and in-depth information on selected issues. Available at http://www.emcdda.europa.eu/attachements.cfm/att_142760_EN_L U-NR2009.pdf

Postma, M. (2004). Public expenditure in the field of drugs in the EU. In EMCDDA (2004), Public expenditure on drugs in the European Union 2000-2004. Lisbon: EMCDDA. Available at http://snapshot.emcdda. europa.eu/attachements.cfm/att_5626_EN_final\%20expenditure.pdf

Prieto, L. (2010). Labelled drug-related public expenditure in relation to gross domestic product (gdp) in Europe: A luxury good? Substance Abuse Treatment, Prevention, and Policy, 5(9). doi:10.1186/1747-597X-5-9

Raftery, J. (2000). Costing in economic evaluation. British Medical Journal (Economics notes), 320, 1597. doi:10.1136/bmj.320.7249.1597

Ramsted, M. (2006). What drug policies cost: Drug policy spending in Sweden: Work in progress. Addiction, 101(3), 330-338.

Reuter, P., Ramstedt, M., \& Rigter, H. (2004). Developing a framework for estimating government drug policy expenditures. Lisbon: EMCDDA.

Rigter, H. (2006). What drug policies cost: Drug policy spending in the Netherlands in 2003. Addiction, 101(3), 323-329. doi:10.1111/j.1 360-0443.2006.01337.x

Ritter, A. (2009). Methods for comparing drug policies - The utility of composite Drug Harm Indexes. International Journal of Drug Policy. 20(6), 475-479. doi:10.1016/j.drugpo.2009.02.012

Sakoman, S., Raboteg-Šarić, Z. \& Kuzman, M. (2002). Raširenost zlouporabe sredstava ovisnosti među hrvatskim srednjoškolcima (The incidence of substance abuse among Croatian high school students). Društvena istraživanja, 11(2-3), 311-334. 
DRUŠ. ISTRAŽ. ZAGREB GOD. 24 (2015), BR. 1, STR. $1-20$

JURLINA ALIBEGOVIĆ D., SLIJEPČEVIĆ, S ASSESSMENT OF..
Šarić, J., Sakoman, S., \& Zdunić, D. (2002). Zlouporaba droga i uključenost $\mathrm{u}$ kriminalno ponašanje (Drug abuse and involvement in criminal behaviour). Društvena istraživanja, 11(2-3), 353-377.

Vander Laenen F., Vandam, L., De Ruyver, B., \& Lievens, D. (2011). Studies of public drug expenditure in Europe: possibilities and limitations, published in UNODC, Bulletin of narcotics: Measurement issues in drug policy analysis. Volume LX, Vienna, United Nations Office on Drugs and Crime; New York, United Nations.

WHO (2010). Atlas on substance use: Resources for the prevention and treatment of substance use disorders. Geneva: World Health Organization. Available at http://www.who.int/substance_abuse/activities/msb atlasfrontncont.pdf

\section{Procjena javnih rashoda u području suzbijanja zlouporabe droga u Hrvatskoi}

Dubravka JURLINA ALIBEGOVIĆ, Sunčana SLIJEPČEVIĆ Ekonomski institut, Zagreb

Literatura navodi da je suzbijanje zlouporabe droga vodeći zdravstveni i društveni problem današnjega društva. Hrvatska u tome nije iznimka, iako pripada zemljama Europske unije sa srednjim stupnjem ovisnosti. Sve je veća važnost vrednovanja javnih politika na području suzbijanja zlouporabe droga. Javni izdaci predstavljaju važan indikator državnih napora u suzbijanju zlouporabe droga. Ovaj članak sadrži rezultate prvog istraživanja javnih rashoda u Hrvatskoj od 2009. do 2012. godine. U radu su procijenjeni ukupni javni rashodi, specificirani i nespecificirani, koji se odnose na suzbijanje zlouporabe droga. Procjena se temelii na podacima koji su prikuplieni anketnim ispitivanjem glavnih dionika na području suzbijanja zlouporabe droga $u$ Hrvatskoj. U članku se analiziraju i javni rashodi prema funkcijskoj klasifikaciii, kako bi se stekao uvid u njihovu krajnju namjenu. Rezultati upućuju na to da se najveći dio ukupnih javnih rashoda odnosi na javnu funkciju javnog reda i sigurnosti, dok se manji dio odnosi na zdravstvo, socijalnu zaštitu i obrazovanje.

Ključne riječi: politika droga, javni rashodi, evaluacija, Hrvatska 